\title{
Response of bivalve populations to drying disturbance and life history traits of two Pisidium species (Bivalvia: Sphaeriidae) in a reservoir of the French Upper Rhone river
}

\author{
Jacques Mouthon* \\ Cemagref, UR MALY, 3 bis quai Chauveau, CP 220, 69336 Lyon cedex 09, France
}

Received 10 November 2010; Accepted 28 February 2011

\begin{abstract}
The dam reservoirs of the Upper Rhone were drained every three years until 2003, and the water level of the Villebois reservoir was lowered by $1.5 \mathrm{~m}$. This resulted in considerable drying of its littoral habitats and the disappearance of the abundant macro-invertebrates that live in them. This study investigates the response to this drying disturbance of bivalve populations and especially of the life history traits of the two potamic species, Pisidium moitessierianum and Pisidium supinum. The low density of these bivalves observed during the months following the drying of May 2003 until spring 2004 shows that the contribution of drift in population recovery was very limited during this period. Due to the faster turnover of its cohorts and a higher increase in litter size in 2004, P. moitessierianum once again dominated bivalve communities from 2005 onwards. In the Villebois reservoir recovery of bivalve communities in terms of structure and density was total three years after the drying of 2003. Observations suggest an increase in litter size and continuous recruitment: the reproductive strategy adopted by these bivalves represent response to the fall in numbers on the one hand, and to considerable magnitudes of temperature and flow rates on the other hand, enabling the rapid adjustment of populations to drying disturbance and variations in environmental conditions. Taking into account the response of bivalve populations to this event, its effects are comparable to those of a supra-seasonal drought (Lake, 2003, Freshw. Biol., 48, 1161-1172).
\end{abstract}

Key words: Flushing / bivalve / population dynamics / life cycle / competition

\section{Introduction}

Hydropower dam reservoirs store water but also accumulate large quantities of sediment through time that have to be removed periodically by flushing. In the Upper Rhone coordinated flushing of the different dams was organised every three years from 1969 to 2003, after which it were suspended temporarily. Flushing is performed after a fall in the water level in order to optimise it and avoid clogging the banks with sludge. The consequences on the biocenosis of successive flushings, equivalent to a ramp disturbance (i.e. a disturbance increasing steadily over time) (Lake, 2000), have been well documented (Crosa et al., 2010; Renöfält et al., 2010, and references herein). However, the specific impact of rapid lowering of the water level and temporary drying of riverine habitats of rivers and reservoirs on their macro-invertebrate communities has received scant attention (Walker et al., 1992).

\footnotetext{
*Corresponding author: jacques . mouthon@cemagref.fr
}

Located downstream of the main dams built on the Upper Rhone, the Villebois reservoir has a well developed littoral zone densely colonised by macro-invertebrates and appears especially promising for this type of study. Since the construction of the Villebois dam the rheophilic species of this sector has been replaced by limnophilic species (Fruget, 2003). These include numerous molluses with several potamic species such as Pisidium moitessierianum and P. supinum (Meier-Brook, 1975; Mouthon, 1981, 1999). Pisidiid clams are hermaphroditic, capable of selffertilization and ovoviviparous. The young develop inside the marsupium or brood sac on the inner demibranches of the gills and only one developmental stage can be observed at any one time (Odhner, 1929; Thomas, 1959; Heard, 1965; Meier-Brook, 1970, 1977; Mackie, 1978). These bivalves are interstitial suspension feeders (Lopez and Holopainen, 1987). The life history of P. moitessierianum has only been studied in the littoral area of a Finnish lake (Holopainen, 1979) while that of $P$. supinum remains unknown. Furthermore, no information is available on their resistance to drying or the capacity of their population 

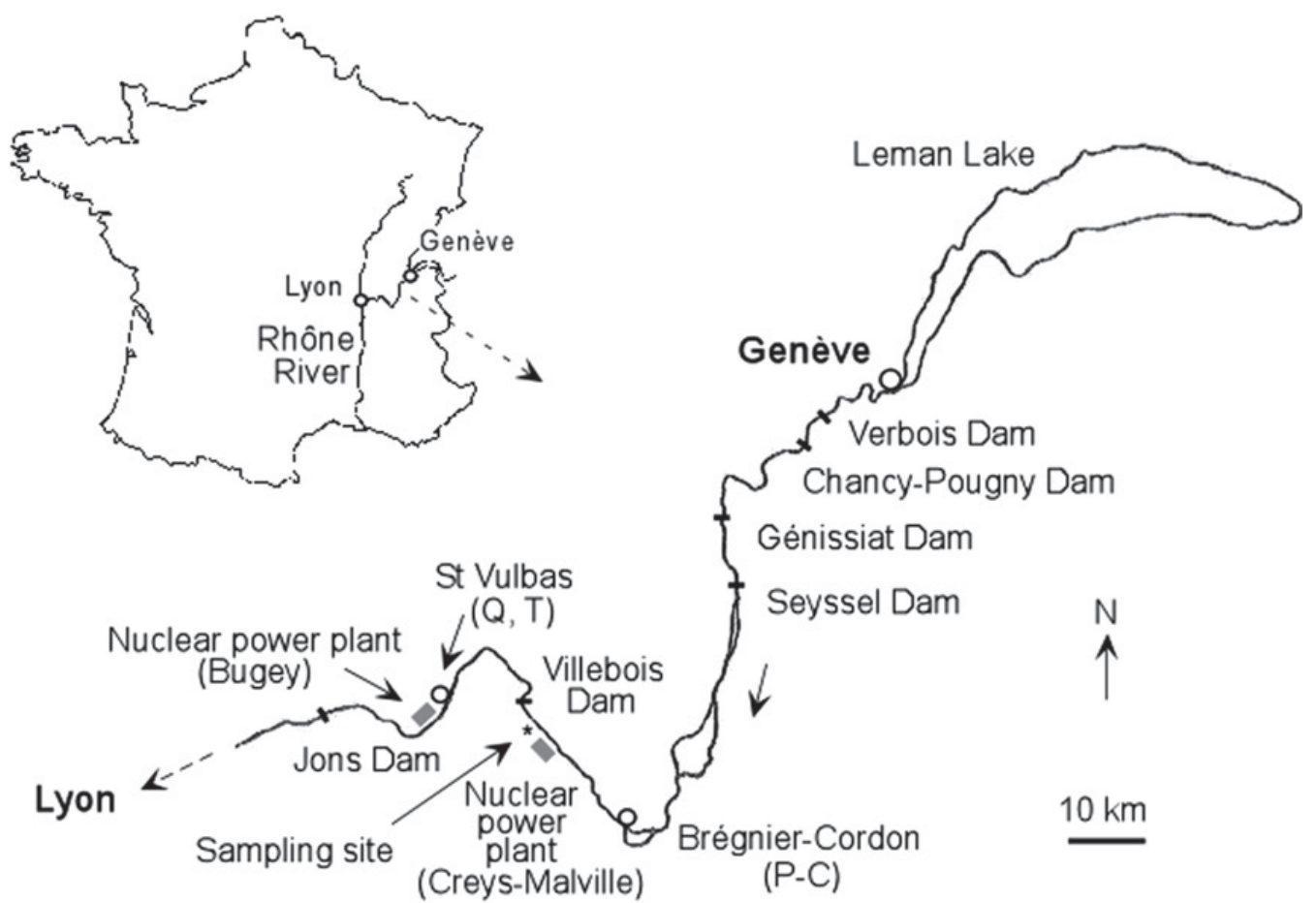

Seyssel Dam
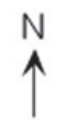

$10 \mathrm{~km}$

Fig. 1. Study area and location of the mollusc collection site, discharge (Q), temperature (T), and physico-chemical (P-C) recording sites.

to recover after this type of event. During the flushing operations of 2003, the water level of Villebois reservoir was lowered by about $1.5 \mathrm{~m}$ from 16 to 28 May and the fine sediments that constitute most of its littoral substrate underwent considerable drying. The purpose of this study was to examine the response to drying disturbance of bivalve population dynamics and especially the life history traits of these two potamic Pisidium species.

\section{Study site}

The reservoir of Villebois is located on the Upper Rhone, between Lake Geneva and the city of Lyon, approximately $80 \mathrm{~km}$ downstream from Génissiat Dam (height: $104 \mathrm{~m}$ ) (Fig. 1). The construction of Villebois Dam (height: $9.7 \mathrm{~m}$ ), has formed a $28 \mathrm{~km}$ long reservoir which supplies a hydropower station. Current velocity in the reservoir is generally lower than $0.50 \mathrm{~m} . \mathrm{s}^{-1}$ and water turnover occurs in less than 24 hours (CNR data). Apart from flushing periods, the water-level fluctuations of the reservoir do not exceed $0.50 \mathrm{~m}$.

The hydropower developments built on the Upper Rhone during the last sixty years have radically altered the natural flow rhythms of the water (Bravard, 1987). The peak flows were generally accompanied by an abrupt fall in water temperature owing to addition of cold water from snow melt in the spring and also to flushing in the Génissiat Dam.

The waters of the Rhone are alkaline, rich in minerals, in particular calcium. According to the French water quality standard (SEQ-Eau, available on http://sierm. eaurmc.fr/eaux-superficielles/fichiers-telechargables/grillesseq-eau-v2.pdf). They are of good quality regarding organic, oxidizable, phosphorated and nitrated materials. The sediment of the reservoir is composed of silt (fraction $2-50 \mu \mathrm{m}=57 \%$ of total dry weight) and fine sand (fraction $50-200 \mu \mathrm{m}=36.5 \%$ of total dry weight) (Mouthon, 2001). Sediment quality is good for organic micropollutants and pesticides, average for PAH (polycyclic aromatic hydrocarbons), and heavy metals (Cd, $\mathrm{Cr}, \mathrm{Ni}$ ).

\section{Materials and methods}

The sector studied is situated on the left bank downstream the Creys-Malville power plant that was decommissioned in 1998 and reached a length of $50 \mathrm{~m}$. Riverine zone is mainly composed of fine sediment. Molluscs were collected monthly from January 2003 to December 2009. The samples were taken out using a rectangular hand-net $(25 \times 18 \mathrm{~cm}, 315 \mu \mathrm{m}$ mesh) pulled perpendicularly to the bank for a distance of one meter. Since sphaeriid bivalves are very numerous at this location, the samples were only taken at two stations at a depth from 0.50 to $1.5 \mathrm{~m}$, each covering $0.25 \mathrm{~m}^{2}$, thus the total area sampled was $0.5 \mathrm{~m}^{2}$. The samples were fixed on-site in $12 \%$ neutralised formaldehyde and sieved at $315 \mu \mathrm{m}$ in the laboratory, where the molluscs were separated from the sediment and identified. The individuals were then counted and their numbers express per $\mathrm{m}^{2}$. 

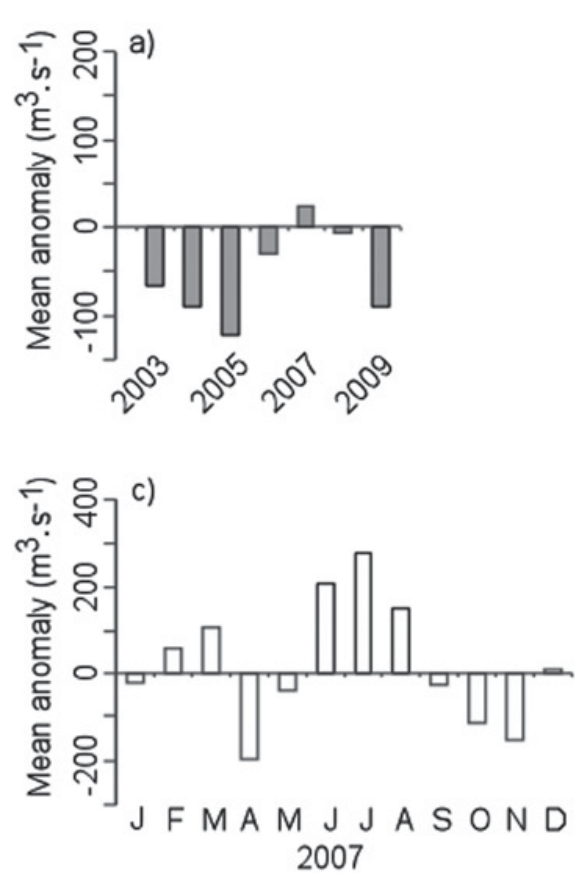
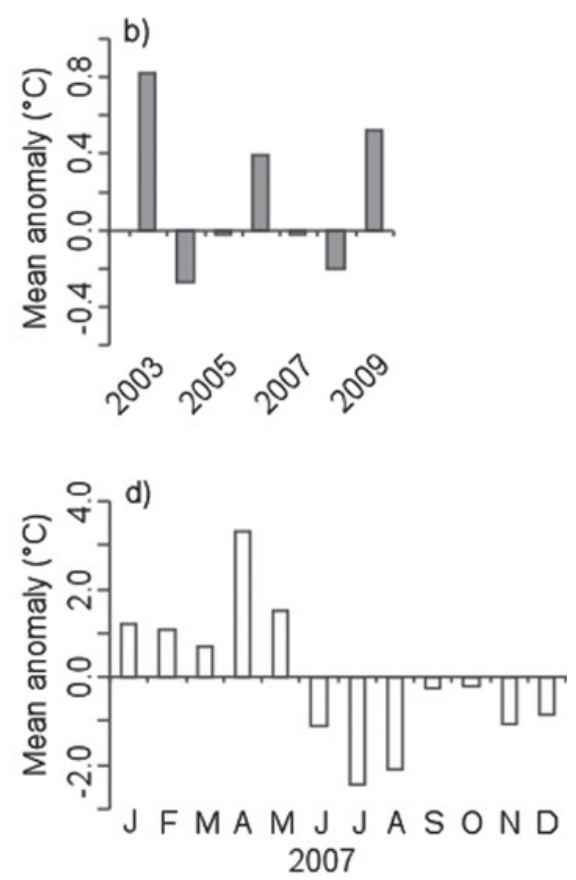

Fig. 2. Annual mean and seasonal anomalies in 2007 relative to mean 1995-2009 values: a) and c) discharge, b) and d) water temperature.

When the number of Pisidium supinum $(P s)$ or P. moitessierianum (Pm) sampled was high $\left(>150\right.$ ind. $\left.\mathrm{m}^{-2}\right)$, individuals of infrequent size classes were set aside, after which a subsample (ranging between 5 and $50 \%$; always representing at least 100 individuals) of the other bivalves was taken randomly. The shell length (SL, largest anteriorposterior dimension across the valves) of the individuals set aside and of those selected was measured with an eye piece micrometer at $25 \times(P s)$ or $40 \times(P m)$ under a binocular microscope, and assigned to size classes of $0.2(P s)$ or $0.05 \mathrm{~mm}(P m)$ width. The resulting histograms were analysed using Bhattacharya's (1967) graphical method available in the FiSAT software distributed by FAO-ICLARM (Gayanilo et al., 1996), which allows the identification of cohorts from continuous histogram data, using Gaussian curve-fitting algorithms. For each cohort, the mean size of the individuals, the number and the standard deviation were established. Thirty adult individuals with $\mathrm{SL} \geq 1.4 \mathrm{~mm},(P s)$, or $\geq 1.0 \mathrm{~mm},(P m)$, were taken randomly each monthly samples and then dissected to establish the number of larvae in the marsupium. The larvae were separated into two size classes: $\mathrm{SL}<0.5$ and $\mathrm{SL}>0.5 \mathrm{~mm}(P s), \mathrm{SL}<0.25$ and $\mathrm{SL}>0.25 \mathrm{~mm}(P m)$. The larvae were then counted and their numbers expressed per $\mathrm{m}^{2}$.

Discharge rates and daily temperature at Saint Vulbas, situated $30 \mathrm{~km}$ downstream from the Villebois Reservoir were supplied by EDF, the French electricity company and physico-chemical data at Brégnier-Cordon $18 \mathrm{~km}$ upstream from the reservoir by the Rhone, Mediterranean, Corsica Water Agency (web site: http://sierm.eaurmc.fr/ eaux-superficielles/index.php).

Densities of bivalves, gravid individuals, shelled larvae and litter size/parent were $\ln (x+1)$ transformed to homogenize variances. An analysis of variance (ANOVA) followed by a Tukey HSD post-hoc test was performed to check differences in bivalve densities between years, and trends in the data series were analysed by linear regression. The statistical analyses used were extracted from the Statistica package library (version 9.0).

\section{Results}

\section{Environmental variables}

Compared to the annual average flow rates and temperatures for the period 1995-2009, the years 2003 to 2009 (except 2007) were the driest and the years 2003, 2006 and 2009 the hottest (Figs. 2a and 2b). In 2007 the flow rates of June, July and August were higher and the temperatures lower than the averages for these months over the last fifteen years (Figs. 2c and 2d). Maximum temperatures ranged from 21.3 to $25.7^{\circ} \mathrm{C}$ while minimum temperatures do not fall below $2.2^{\circ} \mathrm{C}$.

\section{Bivalve population dynamics}

From 2003 to 2009, 101031 molluscs were collected including $90 \%$ bivalves $(86.8 \%$ for Sphaeriidae and $3.2 \%$ for Corbicula fluminea); the absence of macrophytes explained the low density of gastropods. Among the eight species of Sphaeriidae identified only P. moitessierianum and $P$. supinum represented more than $10 \%$ of the total number of these mussels (71.7 and 12\% respectively). We observed significant variations in the mean annual densities of these two species and other bivalve 


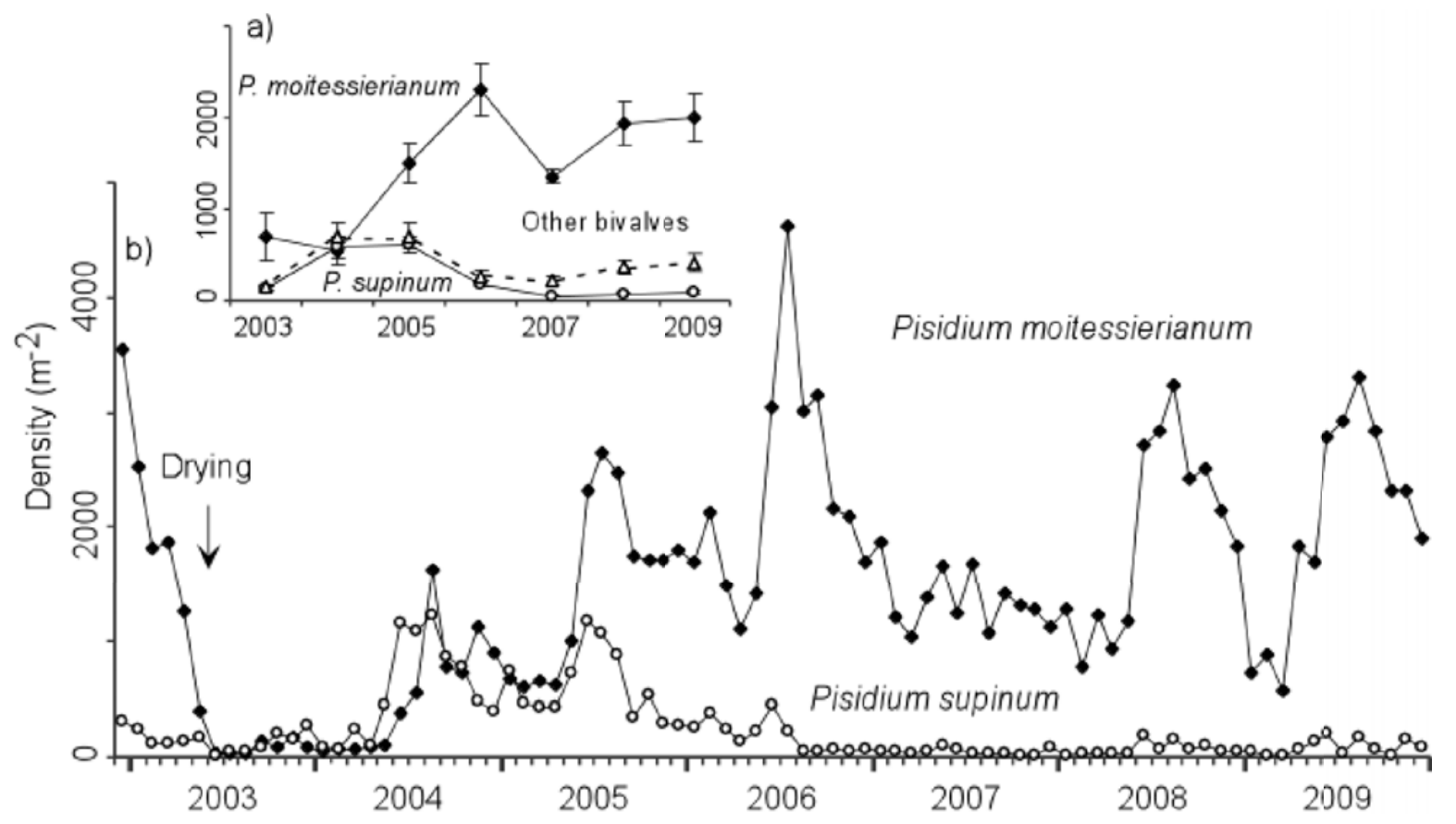

Fig. 3. Annual mean $( \pm S E)$ (a) and seasonal (b) variations in the density of bivalve populations.

populations during the study period (ANOVA, $p<0.001$ ) (Fig. 3a). Densities of $P$. supinum and other bivalves were lowest in 2003 and 2007, and highest in 2004 and 2005. On the contrary, that of $P$. moitessierianum, lowest in 2004, reached its maximum in 2006. In 2004, the densities of the three taxa were close. From 2004 to 2006 the mean annual density of the latter progressively increased (linear regressions, $\left.r^{2}=0.65, p<0.00001\right)$, whereas those of $P$. supinum and the other bivalves declined $\left(r^{2}=0.17\right.$, $p=0.013$ and $r^{2}=0.16, p=0.015$, respectively).

The density of the two species is generally lowest at the end of winter and the beginning of spring, but in 2003 it reached its lowest level in June after a drying period (Fig. 3b). In May and June, densities of P. moitessierianum and $P$. supinum fell from 398 to 26 and from 174 to 16 ind $\mathrm{m}^{-2}$, respectively, while from June 2003 to May 2004 the average number $( \pm S E)$ of the former increased less rapidly than that of the latter $(77.8 \pm 12.5 \mathrm{vs}$. $150.6 \pm 36.1$ ind. $\mathrm{m}^{-2}$ ). In spring 2004 we observed an increase in the population of both species and from June 2005 P. moitessierianum became predominant. The drying period also strongly modified the structure of bivalve communities. In 2003 after this event, the percentage of P. moitessierianum fell from 81.1 to $24.3 \%$, reaching only $29.6 \%$ in 2004 and then $53.3 \%$ in 2005 . However, from 2006 it once again composed more than $78 \%$ of the total number of bivalves.

\section{Life history variations}

The life history of the two Pisidium are described using the results supplied by Bhattacharya's method.
Observation of the two species revealed two cohorts per year, the first in May-June (early cohort), the second from July to September (late cohort) (Figs. 4 and 5). In 2003, early cohorts (E03) appeared before the drying period and the oldest individuals (cohorts E02 for Pm and L01 for Ps) disappeared during the drying period.

In 2003 and 2004 the early cohorts of $P$. supinum appeared in May as indicated by the fall in mean size of individuals and the increase of their numbers. Nonetheless, since the mean size of the late cohorts born in 2002 and 2003 (L02 and L03, respectively) was close to that of the newborn, the early and late cohorts (L02 and E03, L03 and E04) were confounded. In 2005 and 2006 the early cohorts did not appear until June.

Examination of the size of gravid individuals with shelled larvae $>0.25 \mathrm{~mm}(P m)$ or $>0.5 \mathrm{~mm}(P s)$ showed that the adults of both cohorts present each year in spring participated in the birth of two new cohorts. Three months after their birth the individuals of the early cohorts incubated shelled larvae and immediately following the end of summer the young released by these adults joined the numbers of the late cohort. Therefore the growth of the latter which did not benefit from optimum thermal conditions remained generally low until the following spring for both species. Each cohort therefore reproduced 2 to 3 times (iteroparity). For each population, minimum mature size, minimum parent size with shelled larvae and maximum length of larvae remained relatively constant during the period studied (Table 1). Figure 6 shows that parents contain eggs or (and) larvae before shell formation or shelled larvae all year round.

The lifespan of cohorts of $P$. supinum is close to or exceeds two years (27 months for E03), except for E04 

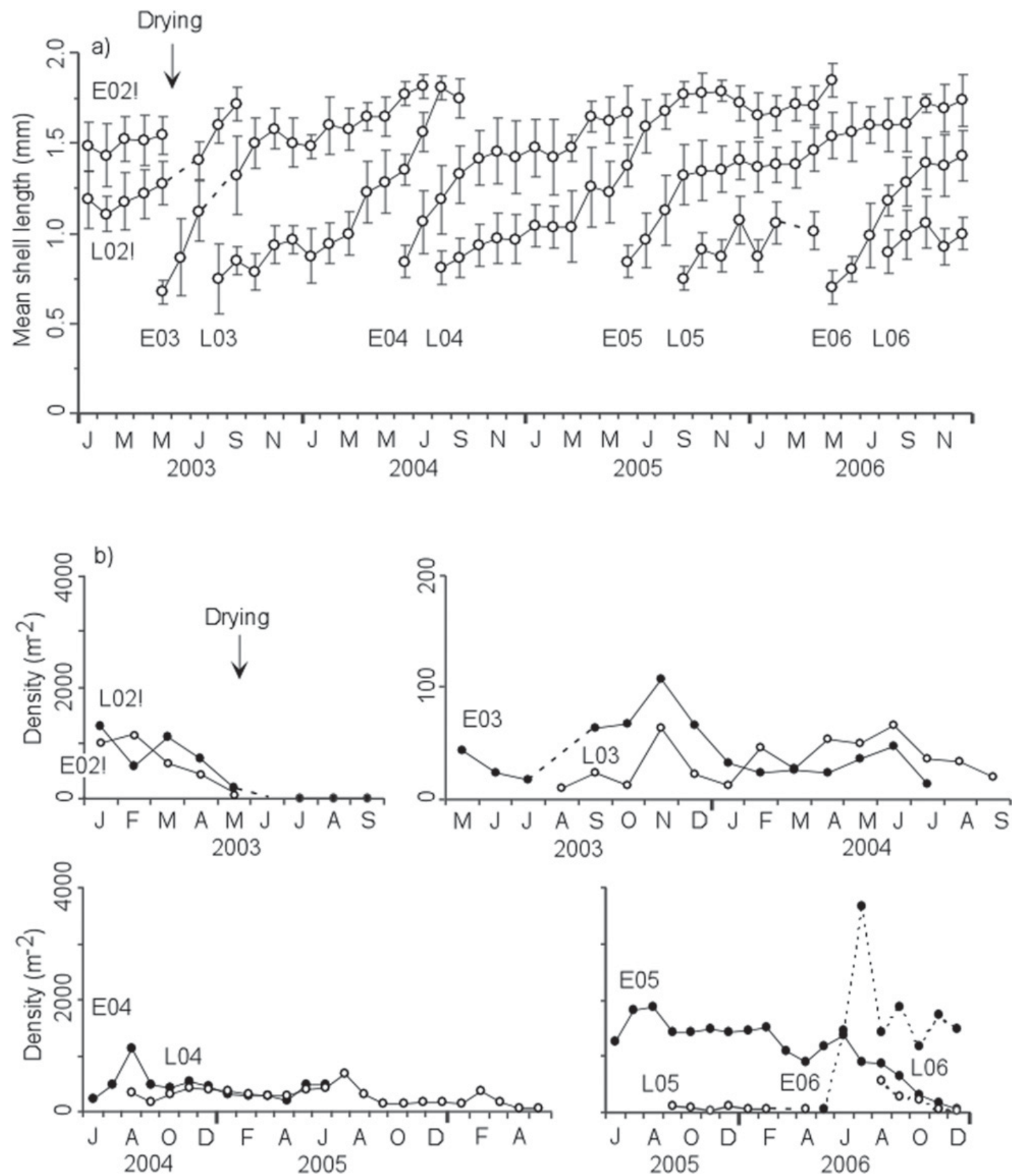

Fig. 4. a) Mean cohort shell lengths (open circles) in monthly samples of the Pisidium moitessierianum population. Vertical bars are standard deviations. Dotted lines indicate the presumed changes in mean lengths. ( $\mathrm{E}=$ early cohort, $\mathrm{L}=$ late cohort.) b) Seasonal variations in the density of every cohort.

which only reached 17 months. However, that of the cohorts of P. moitessierianum lasts from a year (E03, L03 and E04), except for L05 which was only observed for eight months, to nearly two years (L04, E05) (Figs. 4 and 5).

From 2004 the peak density of the early cohort was always higher than that of the late cohort. This occurred in
June (P. supinum) or in July-August (P. moitessierianum). The numbers of the late cohort of both species born in 2005 were low. In the first species the maximum size reached by cohorts L02, E03, L03, and L04 progressively decreased, passing from $4.09,3.78,3.32$ to $3.1 \mathrm{~mm}$ although there was no trend for this trait in the second bivalve. The maximum shelled length of 

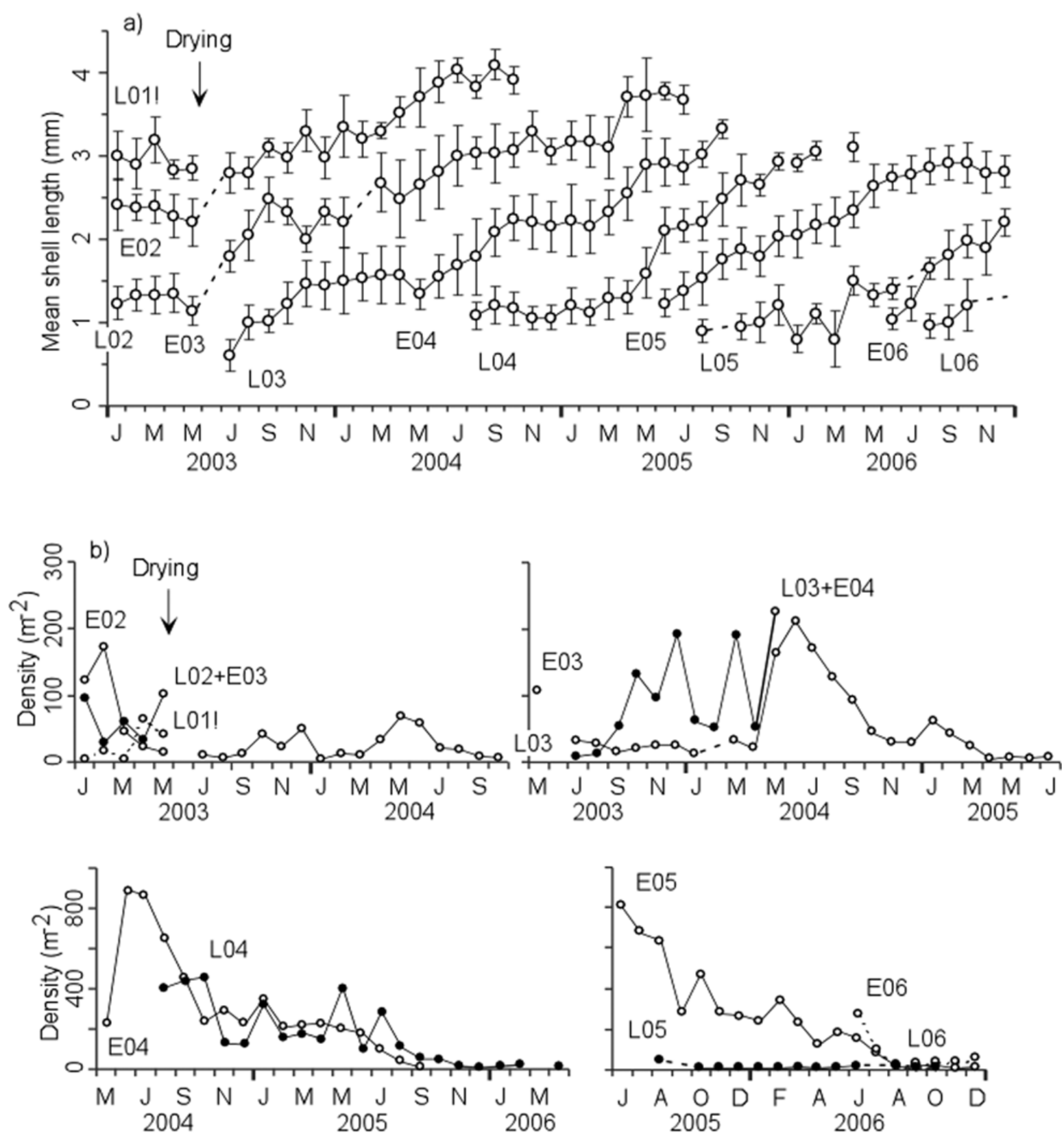

Fig. 5. a) Mean cohort shell lengths (open circles) in monthly samples of the Pisidium supinum population. Vertical bars are standard deviations. Dotted lines indicate the presumed changes in mean lengths. ( $\mathrm{E}=$ early cohort, $\mathrm{L}=$ late cohort.) $b)$ Seasonal variations in the density of every cohort.

$P$. moitessierianum increased from 1.88 to $2.13 \mathrm{~mm}$ whereas that of $P$. supinum decreased from 4.40 to $3.52 \mathrm{~mm}$ (Figs. 4 and 5, Table 1).

From 2004 to 2006 the number of gravid individuals and shelled larvae increased for $P$. moitessierianum (linear regressions, $r^{2}=0.43, p<0.0001$ and $r^{2}=0.28, p<0.001$, respectively) but decreased for $P$. supinum $\left(r^{2}=0.24\right.$, $p<0.01$ and $r^{2}=0.35, p<0.001$, respectively) (Figs. 6a and 6b). From 2005 the mean numbers of gravid individuals and shelled larvae of $P$. moitessierianum were higher than those of $P$. supinum (Table 1). Conversely, the litter size (number of shelled larvae/parent) of the two species decreased significantly $\left(r^{2}=0.15, p<0.05\right.$ and $r^{2}=0.35, p<0.001$, respectively) (Fig. 6c).

\section{Discussion}

In the French Upper Rhone P. moitessierianum and $P$. supinum populations produced two cohorts per year. The lifespan of the first varied from 13 to 22 months while that of the second from 17 to 27 months.

There are considerable differences between the life history of $P$. moitessierianum in the Upper Rhone and that 
J. Mouthon: Ann. Limnol. - Int. J. Lim. 47 (2011) 175-184

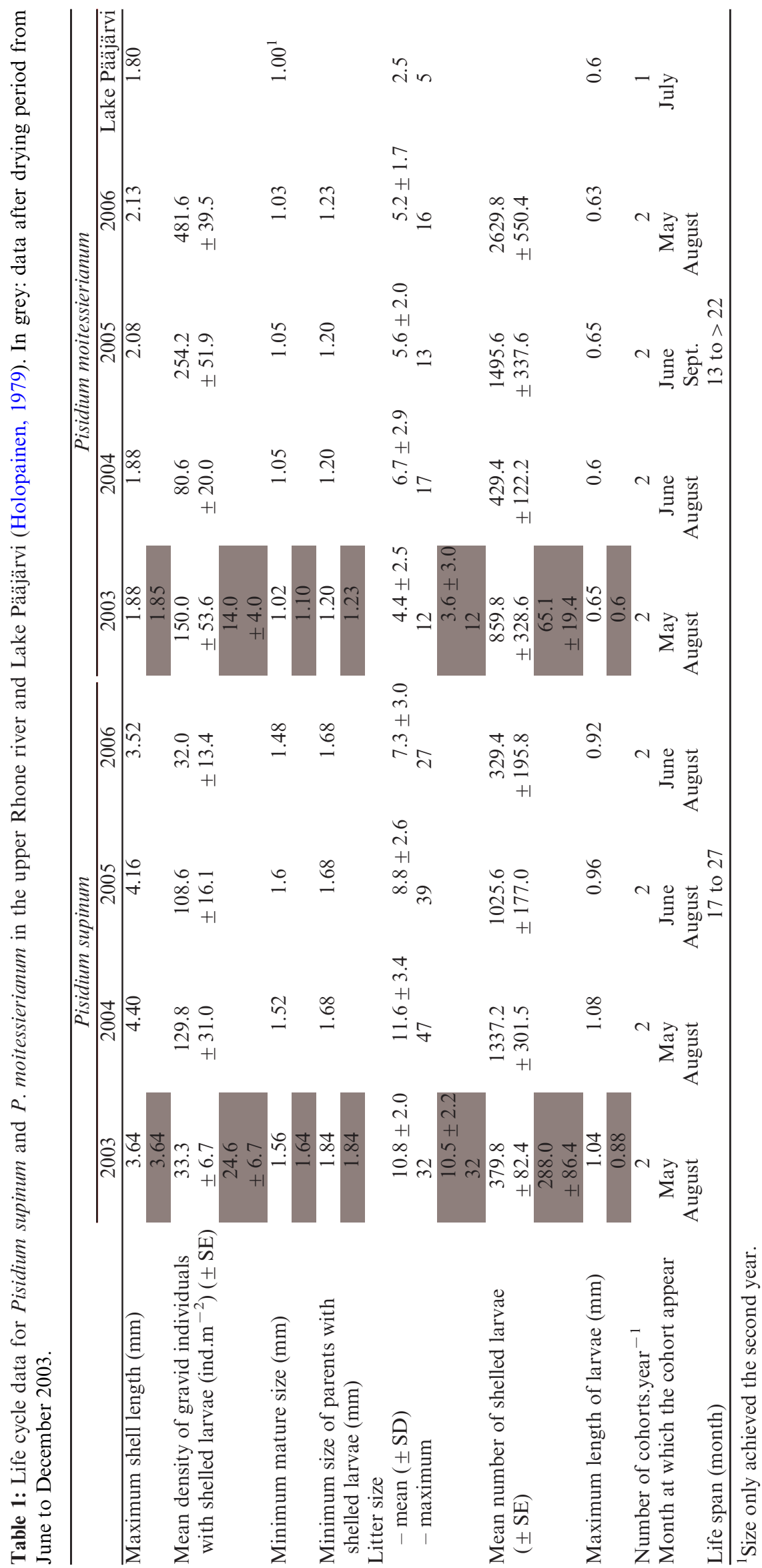



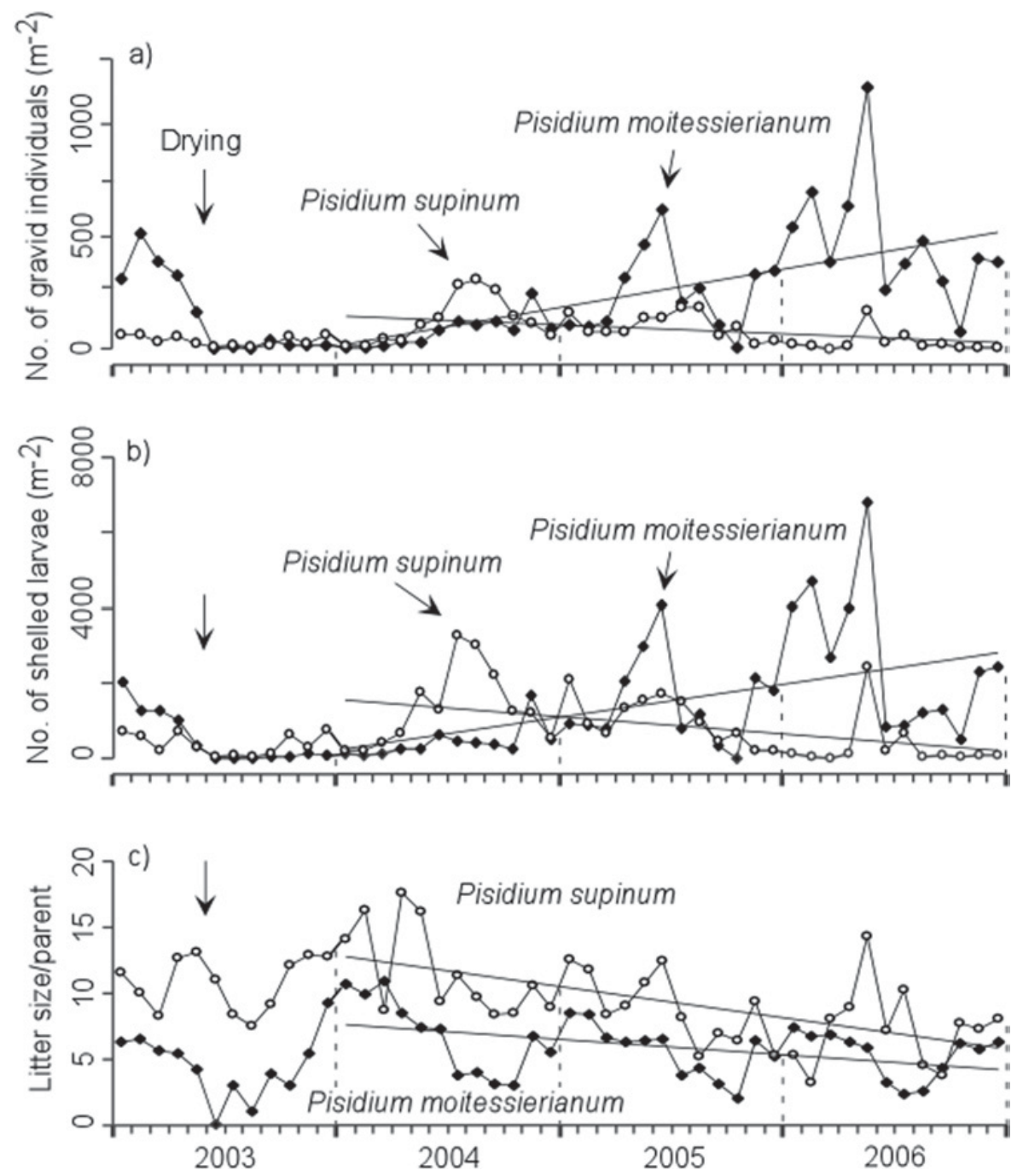

Fig. 6. Seasonal variations of number of gravid individuals with shelled larvae (a), number of shelled larvae incubated (b) and litter size/parent of Pisidium moitessierianum and P. supinum (c).

of the same species in Lake Pääjärvi (southern Finland) (Holopainen, 1979). In the littoral zone of this lake, it only produces one cohort per year (semelparity vs. iteroparity for the Rhone population), eggs are laid in summer and shelled larvae released in spring of the next year, whereas in the Rhone the individuals of the early cohort incubated shelled larvae three months after their birth. Mean and maximum number of shelled larvae/parent are very low, i.e. 2.5 and 5, vs. 5.2 to 6.7 and 13 to 17 , respectively for the Rhone population (Table 1). Much cold water of this lake compared to that of the Rhone (1-20 vs. 3.1-25.7 ${ }^{\circ} \mathrm{C}$ ) explains most of these differences. Nonetheless, in spite of its low rate of recruitment, its density can reach 900 ind. $\mathrm{m}^{-2}$ in places (Holopainen, 1979). For the two populations, the minimum mature size and maximum length of larvae also remain relatively constant (1.0 to 1.05 and 0.6 to 0.65 , respectively).

The fall in bivalve density observed in May (start of falling water levels) and June 2003 (three weeks after the water level rose) shows that the mortality of the molluscs of emerged habitats was considerable, since the dry hot weather during this period led to the drying of fine sediments. Pisidium species living in temporary habitats are dessication-resistent (Danneel and Hinz, 1974; Bleck and Heitkamp, 1980). However, these two species that only inhabit perennial systems do not apparently develop specific resistance mechanisms.

Drift and reproduction are the two main patterns by which species reconstitute their populations. As recruitment after drying was low and drift contributions apparently limited, the density of both populations remained very low (Fig. 3). The low flow rates of the years 2003 to 2005 and the scarcity of potential upstream donor sites between June 2003 and 2004, since the water level had also been lowered in the upstream reaches, explain the slightness of drift during this period (Fig. 2a). The increase of numbers coincided with the start of the reproduction period in spring 2004. Recovery following natural drought occurs relatively quickly (Boulton, 2003; Lake, 2003). In the Villebois reservoir bivalve recovery in terms of structure and density was total three years after the 2003 drying. It was also noted that the highest flow rates 
and coolest temperatures in comparison to the mean of the period 1995-2009 observed from June to August 2007 had a strong impact on the recruitment of $P$. moitessierianum as revealed by the lack of any density peak during the summer of this year (Figs. 2c, $2 \mathrm{~d}$ and 3 ).

After a severe habitat disturbance Valvata piscinalis in an English pond produced two cohorts instead of one to recover its population (Lodge and Kelly, 1985). On the contrary, the number of cohorts of these two bivalves did not vary between 2003 and 2006, in the present case. Nonetheless it was seen that as soon as the density of $P$. moitessierianum increased, there was an extension of the lifespan of the late cohort in 2004, likewise for the early cohort in 2005 and 2006 (Fig. 4).

The increase of litter size when density fell was greater in $P$. moitessierianum, in spite of its small size, than in $P$. supinum; the latter, which was not very abundant before the drying, had probably reached its maximum capacity for producing embryos. This phenomenon was also observed for $P$. subtruncatum in the Saone river (Mouthon, 2005). It suggests the existence of compensation mechanisms making it possible to readjust numbers. In pisidiid clams the number of extramarsupial larvae (just before release) is always much lower than the number of initial embryos and parents used intramarsupial suppression of embryos to control the number of young released (Meier-Brook, 1977). Meier-Brook explains this phenomenon by the action of a growth inhibitor in the brood sac, though the nature of this inhibitor remains unknown (Guralnick, 2004).

Opposite trends of population density, number of gravid individuals, number of shelled larvae, maximum shelled size, and the decrease of the maximal size of cohorts of $P$. supinum revealed not only probable competition between $P$. moitessierianum and $P$. supinum but also with other bivalves whose density evolved in parallel with that of $P$. supinum (Fig. 3). The progressive fall in litter size of both species from 2004 to 2006, whereas total density of bivalves increased, strongly supports this argument (Table 1, Fig. 6). Furthermore the fall in numbers of the late cohort vs. the early cohort of $P$. moitessierianum in 2005 and 2006 also suggests the existence of competition between the individuals of both cohorts (Fig. 4b).

Gravid individuals incubate shelled larvae throughout the year and they are a continuous release of larvae. The ability to produce young throughout the year has also been mentioned in Sphaerium and Musculium (Mackie, 1979) and in populations of the gastropod Potamopyrgus antipodarum (Gray), from New Zealand, Australia and Europe (Winterbourn, 1970; Fretter and Graham, 1978; Schreiber et al., 1998). However, in pisidiid bivalves this reproduction strategy is rather unusual. It has been observed in Pisidium conventus Clessin, living in the deep zones of lakes where the temperature remains cold throughout the year (Meier-Brook, 1970; Holopainen, 1979), in a population of Pisidium clarkeanum Nevill, from Hong Kong (Morton, 1986) and in P. tenuilineatum in the Upper Rhone (Mouthon, 2008).
Lake (2003) makes the distinction between seasonal, predictable droughts (as in Mediterranean rivers) and supra-seasonal, unpredictable droughts, in timing and duration. In the first case organisms develop specific life strategies with dessication-resistant stages and are drought-adapted; its impact on communities is limited and subsequent recovery rapid. In the second case organisms do not develop specific adaptation strategies resist this type of event poorly, with a strongly marked impact on communities (Lake, 2003; Boulton, 2003, and references herein). The drying of the littoral zone of the Upper Rhone, resulting from dam flushing, is comparable to the effects of a supra-seasonal drought (substantial lowering of the water level) although in this particular case the drying was predictable (every three years, in May). Indeed the impact on pisidiid populations was dramatic and time to total recovery relatively long (three years).

In spite of the protection provided by their valves the Pisidium species inhabiting this reservoir are more exposed to drying events than insects and crustaceans, which are more mobile and can shelter in the main channel, or than oligochaetes which are capable of burying themselves deep in the fine sediment and then into the hyporheic zone, thereby escaping their drying habitat. However the more rapid lowering of the water level before flushing (1.5 min a few days) compared to more progressive lowering caused by drought and the possibility of dry, sunny weather during the uncovering of littoral habitats considerably reduces these possibilities. The next flushing is planned for May 2011, i.e. eight years after that of 2003. Obviously, the timing of the supra-seasonal drying period is unpredictable. Therefore its consequences on aquatic biota could be even more dramatic.

Finally pisidiid clams showed poor resistance to a brief period of drying of their habitat, but high adjustment following this type of disturbance. Due to greater plasticity of its life history and greater increase in its litter size $P$. moitessierianum once again dominated bivalve communities three years after drying. The observations performed suggest that an increase in litter size is a response of pisidiid clams to a fall in their numbers. However, further studies are needed to determine the nature of this mechanism and determine whether the reproduction strategy (continuous recruitment) adopted by these two bivalves as well as by $P$. tenuilineatum (Mouthon, 2008), is specific to these species or, as suggested by the life history of $P$. moitessierianum in Lake Pääjärvi (Holopainen, 1979), a response to strong magnitudes of temperature and flow rates, permitting rapid adjustment of a population to variations in environmental conditions.

\section{References}

Bhattacharya C.G., 1967. A simple method of resolution of a distribution into Gaussian components. Biometrics, 23, 115-135. 
Bleck V. and Heitkamp U., 1980. Ökophysiologische Untersuchungen an Pisidium personatum Malm, 1855 und Pisidium obtusale (Lamarck, 1818) (Bivalvia, Sphaeriidae). Zool. Anz., Jena, 205, 162-180.

Boulton A.J., 2003. Parallels and constrasts in the effects of drought on stream macroinvertebrates assemblages. Freshw. Biol., 48, 1173-1185.

Bravard J.P., 1987. Le Rhône du Léman à Lyon, La manufacture, Lyon.

Crosa G., Castelli E., Gentili G. and Espa P., 2010. Effects of suspended sediments from reservoir flushing on fish and macroinvertebrates in an alpine stream. Aquat. Sci., 72, 85-95.

Danneel I. and Hinz W., 1974. Trockenresistenz dreier Pisidiumpopulationen (Bivalvia) in Abhängigkeit von der relativen Luftfeuchtigkeit. Hydrobiologia, 45, 39-43.

Fretter V. and Graham A., 1978. The Prosobranch molluscs of Britain and Danemark. Part 3: Neritacea, Viviparacea, Valvatacea, terrestrial and freshwater Littorinacea and Rissoacea. J. Mollusc Stud., Suppl., 5, 101-152.

Fruget J.P., 2003. Changements environnementaux, dérives écologiques et perspectives de restauration du Rhône français : bilan de 200 ans d'influences anthropiques. VertigO, 4, 1-17.

Gayanilo F.C., Sparre P. and Pauly D., 1996. FAO-ICLARM stock assessment tools, Food and Agriculture Organization of the United Nations, Rome, Computed information series, 8 .

Guralnick R., 2004. Life-history patterns in the brooding freshwater bivalve Pisidium (Sphaeriidae). J. Moll. Stud., 70, 341-351.

Heard W.H., 1965. Comparative life histories of North American pill clams (Sphaeriidae: Pisidium). Malacologia, 2, 381-411.

Holopainen I.J., 1979. Population dynamics and production of Pisidium species (Bivalvia, Sphaeriidae) in the oligotrophic and mesohumic lake Pääjärvi, southern Finland. Arch. Hydrobiol., Suppl., 4, 466-508.

Lake P.S., 2000. Disturbance, patchiness, and diversity in streams. J. N. Am. Benthol. Soc., 19, 573-592.

Lake P.S., 2003. Ecological effects of perturbation by drought in flowing waters. Freshw. Biol., 48, 1161-1172.

Lodge D.M. and Kelly P., 1985. Habitat disturbance and the stability of freshwater gastropod population. Oecologia, 68, 111-117.

Lopez G.R. and Holopainen I.J., 1987. Interstitial suspensionfeeding by Pisidium spp. (Pisidiidae: Bivalvia): a new guild in the lentic benthos? Am. Malac. Bull., 5, 21-30.

Mackie G.L., 1978. Are sphaeriid clams ovoviviparous or viviparous? The Nautilus, 92, 145-147.

Mackie G.L., 1979. Growth dynamics in natural populations of Sphaeriidae clams (Sphaerium, Musculium, Pisidium). Can. J. Zool., 57, 441-456.
Meier-Brook C., 1970. Untersuchungen zur Biologie einiger Pisidium-Arten (Mollusca; Eulamellibranchiata; Sphaeriidae). Arch. Hydrobiol., Suppl., 38, 73-150.

Meier-Brook C., 1975. Der ökologische Indikatorwert mitteleuropäischer Pisidium Arten (Mollusca, Eulammellibranchiata). Eiszeit. Gegenw., 26, 190-195.

Meier-Brook C., 1977. Intramarsupial suppression of fetal developpement in Sphaeriid clams. Malacol. Rev., 10, 53-58.

Morton B., 1986. The population dynamics and life history tactics of Pisidium clarkeanum and $P$. annandalei (Bivalvia: Pisidiidae) sympatric in Hong Kong. J. Zool., 210, 427-449.

Mouthon J., 1981. Typologie des Mollusques des eaux courantes. Organisation biotypologique et groupements socioécologiques. Ann. Limn., 17, 143-162.

Mouthon J., 1999. Longitudinal organisation of the mollusc species in a theoretical French river. Hydrobiologia, 390, $117-128$.

Mouthon J., 2001. Life cycle and population dynamics of the Asiatic clam Corbicula fluminea (Bivalvia: Corbiculidae) in the Rhône River at Creys-Malville (France). Arch. Hydrobiol., 151, 571-589.

Mouthon J., 2005. Life cycle and population dynamics of Pisidium subtruncatum Malm (Bivalvia: Sphaeriidae) in the Saône, a large lowland river, at Lyon (France): environmental influences. Arch. Hydrobiol., 163, 539554.

Mouthon J., 2008. First study of the life cycle of Pisidium tenuilineatum Stelfox, 1918 (Bivalvia, Sphaeriidae). Basteria, $72,45-56$.

Odhner N.H., 1929. Die Molluskenfauna des Täkern. Sjon Täkerns Fauna och Flora, 8, 1-129.

Renöfält M.B., Jansson R. and Nilsson C., 2010. Effects of hydropower generation and opportunities for environmental flow management in Swedish riverine ecosystems. Freshw. Biol., 55, 49-67.

Schreiber E.S.G., Glaister A., Quinn G.P. and Lake P.S., 1998. Life history and population dynamics of the exotic snail Potamopyrgus antipodarum (Prosobranchia: Hydrobiidae) in Lake Purrumbete, Victoria, Australia. Mar. Freshwater Res., 49, 73-78.

Thomas G.J., 1959. Self-fertilization and production of young in a sphaeriid clam. The Nautilus, 72, 131-140.

Walker K.F., Thoms M.C. and Sheldon F., 1992. Effects of weirs on the littoral environment of the river Murray, South Australia. In: Boon P.J., Calow P. and Petts G.E. (eds.), River conservation and management, John Wiley \& Sons, Chichester, 271-292.

Winterbourn M.J., 1970. Population studies on the New Zealand freshwater gastropod, Potamopyrgus antipodarum (Gray). Proc. Malacol. Soc. Lond., 39, 139-149. 